\title{
Hearing of Fetus
}

\author{
河 村 正 三* \\ SHOzŌ KAWAMURA, M.D.
}

生れたばかりの新生児が聴力をもっているのか 否か。若し聴力があるとすれば胎生期のいつ頃か， らあるのか.この問題については古くから多くの 探究が行なわれてきた。殊に近年になってコンピ ユータが聴力検査に導入されるようになり，他覚 的聴力検查の信頼度が著るしく向上してきたのに 伴って，胎児に対する聴力検查（?）の報告も及 られるようになってきた。このようなことは胎児 の発生解剖や聴覚の生理学的発達の過程を解明す る上には大いに意義あることではあるが，一部の 人がい5よ5な難聴の早期発見とい5よ5な点で は多くの問題点をもっている。これらについて著 者の意見を表明するためにも胎児の聴力を論じて みたいと思う。

\section{新生児は難聴である}

19 世紀の終り頃まで, 生後 1〜2 日目までは全 く聴力がないといら人と，聴力はあるという人が 烈しい議論を行なってきたが，20世紀に入る頃よ り新生児も聴力をもっていることが一般に認めら れるようになってきだ．しかしその聴覚は極めて 未熟なものであるらしい。著者ら 2)が脳波を使用 した他覚的聴力検査を新生児に試みた結果では, 脳波に反応がみとめられるのは生後 2 週間頃から で，それまでは体動として音に反応を示すの久で ある(図1，図2 ). このよ5な反応は恐らく, 聴 覚神経路の比較的末梢部から生ずる無条件反射と

* 順天堂大学医学部教授 (耳鼻咽喉科学)

Professor of Otorhinolaryngology, Juntendo University, School of Medicine

** 第189回順天堂医学会学術集会 (May.30.1974) 〔Jul., 17.1974 受付)
考党られている いうょうな反応を始めとして, 極めてび漫性で, 反射带も広範なのが特徴であり，その他，顔をし かめる，泣きやむ，額にしわをよせる，指や腕を

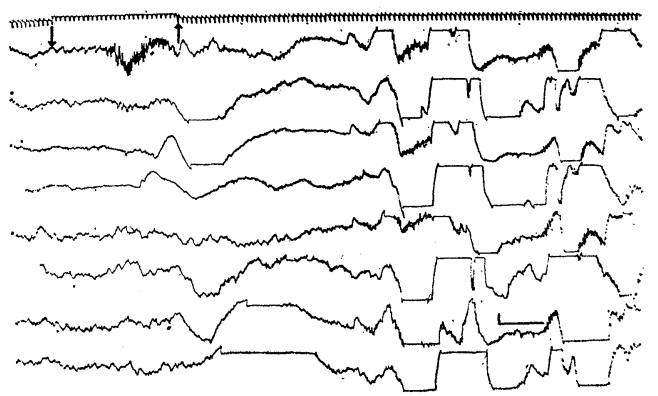

図 1 新生児の音響性反応（生後 3 日）

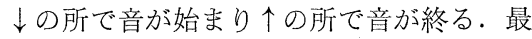
も上の曲線は右前頭部と耳架との間の電位 変動で, 音響刺戟による上眼瞼の活動が認 められる。

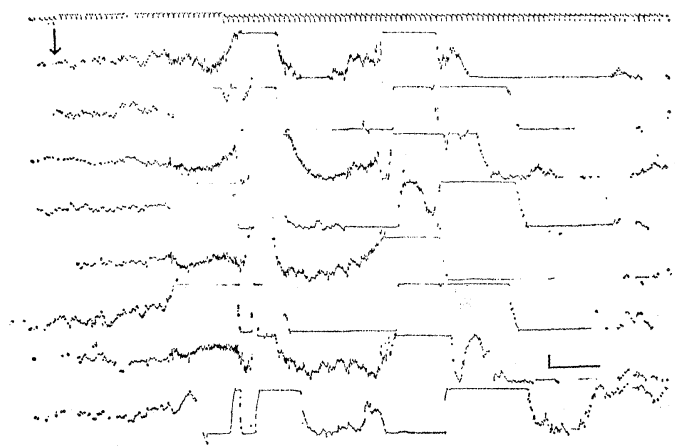

図 2 生後 8 日目の音響性反応 音響刺戟により体動が生じている。 
伸展するなどその出現様式は多様である。しかも そのような反応が出現するには音を相当強大にし なければならず，その值は $70 ９ 0 \mathrm{~dB}$ 位の強さで ある(感覚レベル) $)^{224)}$.

すなわち新生児は音に対して反応を示すという ことは確かとはいえ，それをそのま聴兄ている と解釈するのは無理であり, 聴覚神経路の比較的 末梢部までは音の刺激が伝わっていると考えるの が妥当であろう。しかしこのような反応は相当大 きな音に対しての文認められるもので，乙かも艺 の反応は，恒常的に出現するものでもない，著者 ら2)の観察では生後 7 日目頃までは 70 90 dB の 音に，14日頃飞は 50 70 dB 位の音に反応を示す ようになってくる，脳波上に音響刺激による反応 が出現するのは生後 2 週頃で, 反応の域值も次第 に小さくなって, 生後 2 力月後に大体成人並の域 值に達す。したがって生後 2 力月頃になれば聴觉 たという感覚が成人並になったと解釈してょいと 思う。

このよ5に新生児の聴域值が高い值，いいかえ れば生理的な難聴である原因としては鼓室（中耳 腔）のなかには羊水が残存したり，胎生期の遺物 としての膠様組織が充満して内耳の両円空や耳小 骨の可動性が覀いのが主因である. その他, 外耳 道の狭小, 耳垢や胎脂による外耳道の閉塞, 鼓膜 の弾力性や緊張の悪さ, 聴覚神経路の未熟さなど があげられる。

\section{聴器の発生と発育}

人間の聴器の発生と発育については多くの研究 があり，非態発生に関しては浪流統一された記載 がみられる。外肧葉からは耳介, 外耳道, 鼓膜の 外層, コルチ器を含を膜迷路が, 中肧葉からは耳 小骨，鼓室の上半部。鼓膜の中間層，骨迷路が， 内胚葉からは耳管, 鼓室の下半部, 鼓膜の内層が できる．鼓室の粘膜については全て内肧葉よりで きるという説もある.これらの出現時期と発育の 概略は表 1 に示した，表中の完成とい5語は誕生 時を標準にしたもので，内耳や耳小骨は大体成人 と同じ大きさにまで達しているが，外耳殊に骨性
外耳道や中耳蜂巣は生後に主として発育し, 思春 期頃になって大体完成するのである.

一方, 聴覚神経路の発生についての研究は極め て少なく、まだその全貌は明らかではないが，胎生 24週では髄鞘化が下丘の高さまで達し，32 週で視 床の高さに進さが，出生時でも内側膝状体の高さ では髄鞘化が僅かに認められているにすぎない。 生後 2 力月になると, 内包までは髄莦化されてお り, 大脳皮質の細胞構築学的様式も完成している といら ${ }^{1)}$.

表 1 聴器の発生と発育

\begin{tabular}{|c|c|c|}
\hline \multicolumn{2}{|c|}{ （胎生時期） } & (発生と発育) \\
\hline 3 & 週 & 耳板 (内耳) 出現 \\
\hline 4 & 週 & $\begin{array}{l}\text { 一次外耳道出現 } \\
\text { 耳小骨出現 }\end{array}$ \\
\hline 6 & 週 & $\begin{array}{l}\text { 耳介結節出現 } \\
\text { 三半規管と蝸牛の分化 }\end{array}$ \\
\hline 7 & 週 & 蝸牛の伸長 \\
\hline 8 & 週 & $\begin{array}{l}\text { 鼓室, 耳管出現 } \\
\text { 三半規管完成 }\end{array}$ \\
\hline 11 & 週 & 蝸牛完成 \\
\hline 12 & 週 & $\begin{array}{l}\text { 耳小骨分化 } \\
\text { コルチ器完成 }\end{array}$ \\
\hline 16 & 週 & $\begin{array}{l}\text { 耳小骨の化骨始まる } \\
\text { 骨迷路出現 }\end{array}$ \\
\hline 23 & 週 & $\begin{array}{l}\text { 鼓室の上半部完成 } \\
\text { 骨迷路完成 }\end{array}$ \\
\hline 28 & 週 & 外耳道完成 \\
\hline 30 & 週 & $\begin{array}{l}\text { 耳小骨完成 } \\
\text { 鼓室完成 }\end{array}$ \\
\hline 35 & 週 & 側頭骨の蜂巣化始まる \\
\hline
\end{tabular}

このような組織形態学的な発育と生理機能的発 達の関連性については，まだまだ多くの議論があ るところであるが，前項で述べた新生児の聴反応 及びその後の聴觉の発達と比較してみた場合. 神 経線維の髄鞘化が機能と密接に関係しているとい う説も首肯できる.

\section{胎児も音に反応する}

新生児が音に反応を示すといらこと, 聴器は形 態学的に新生児でほぼ完成していること, 聴覚神 経路の髄鞘化も相当進んでいることなどを考兄れ 
ば胎児が音に反応を示しても不思議ではない。胎 児が音に反応することは 20 世紀前半の妊娠の経験 的記述に始まり, 音響刺激による胎児の測定, 胎 児の心搏数や心音の測定, 更に最近では電子計算 器を使用した聴性誘発反応の測定も行なわれるよ らになってきだ).

胎児の反応の測定方法そのものについても問題 がないわけではないが，これらについては既に多 くの検討が行なわれて和り，その問題点も明らか になっているので，ここではそれらについては言 及しないが，いずれにしても胎児は音響刺激によ り反応を示すということは確かであるらしい.こ のような一連の研究は聴覚の生理学的発達の過程 を解明してゆくためには極めて 重要な研究ではあ るが，一部の人達が目的としている難聴の早期発 見という点になると, 多くの疑問が存在するので ある.

\section{先天性の難聴と胎生期難聴}

新生児が普通の人間よりも聴力が劣っているこ とから胎児はそれ以上に聴力が劣っていると想像 されるが，その実態は現在では全くわかっていな い.しかしそれらはいずれにしても. 正常な聴器 や聴覚神経路の発育過程のものである限りは臨床 的な面では余り問題ではない.

一方，いわゆる小品難聴のなかで，特に午の程 度が極めて高度で, 後になって言語発達が阻害さ れる汪どの難聴の発生率は，同年齢の小児全体の 約 $0.2 \%$ 位である. しかもそれらの約半数が出生 時期以前のものであり，これらを一般先天性難 聴と呼んでいる. 先天性難聴には胎児期にすでに 異常のあったもの (胎生期難聴) と出生周辺期の 障害によるものを区別することができるが，本論 では後者については省略する.

胎生期難聴は更に, 遺伝性ないし家族性難聴と 非遺伝性の胎生期難聴とに区別する。これらはい ずれも母体内で発背中の胎児に種々の障害が加わ った時に, その聴器に異常が生ずるもので, 原因 の種類による特殊性 (artspezifisch) か, あるいは 胎児の発育期時による特殊性 (phasenspezifisch)
として現われてくる，

聴器の発育不全は次の 5 つの型にわけられるこ とが多い。

1. Michel 型

内耳の発育が. 殆んど完全に侵されているもの で, 蝸牛と前庭も未分化である、中耳や外耳は正 常のことが多く，胎生 2 週より 5 週位の発達に相 当している.

2. Scheibe 型

蝸牛は球形虽より分化してくるが，これが末分 化のままであるものをい5。卵形翼や半規管はす でに分化しているもので, 胎生 6 週位の発達に相 当している.

3. Alexander-Mondini 型

螖牛は発達してくるときに基底回転より分化形 成がすすみ，次第に回転ができ，頂の方に及んで くる.この型はその途中の過程で発育が止ったも ので，基底回転の夕は正常に保たれている．胎生 $6 \sim 10$ 週位の発達に相当している.

4. Bing-Siebenmann 型

骨迷路は形態的に大体正常に発達しているが, 膜迷路の形成, 殊に感覚細胞に変生がみられるす ので, 屢々網膜の色素変性などを伴っている.

5. Siebenmann 型

内耳年体正常に発育しているが，中耳に奇形 のタられるものである.

\section{遺 伝 性 難 聴}

遺伝性難聴は必らず出産時に難聴が存在してい るとは限らない。極めて少数ではあるが幼児には 正常な聴力をもっていながら，10才頃から難聴が 出現し, 難聴が除々に進行してくるものがある. 代表的なものとしては耳硬化症や家族性進行性感 “音性難聴などであるが，これらについては省略し た.

一方, 遺伝性難聴は必ずしも感音性難聴とは限 らず伝音性難聴としてあらわれてくることも少な くない.このような遺伝性の伝音難聴は多くの場 合，顔面や耳介をはじめとした奇形をもつものが 多い6). 中耳は中胚葉性の器官であるため, 他の 
中肧葉性器官にも異常が生じ易いのであろ5. 代 表的なものとしては，Van der Hoeve 症候群， Treacher Collins 症候群, Hurler 症候群などで ある。

遺伝性感音性難聴では他の奇形や疾患をもって いるものが少なくない ${ }^{6)}$. 顔面や眼の形態異常, 虹 彩, 網膜, 頭髪, : 皮膚などの色素異常, 口蓋裂, 心蔵奇形, 脊椎破裂, 指の奇形, 腎疾患, 甲状腺 機能障害などがある. 代表的なものとしては Waardenburg 症候群. Usher 症候群. Alport 症候 群などである.

遺伝形式はまだ十分解明されてはいないが，劣 性遺伝のものが最も多く, 次いで優性遺伝の順と なる. 伴性遺伝のものは比較的少ないといわ机て いる。

\section{非遺伝性胎生期難聴}

胎児が発育中に母体に加わった偶発性の障害に より難聴となったものである、大部分の場合, 出 産時に難聴であるが，先天性梅毒によく久られる ように，生後 1〜2 年，あるいは8～20 年頃より 難聴となるものなどもある。斗体に加わる障害と して特に重要なものは感染, 化学物質, 放射線な どがあげられているが，特にこれらが妊娠初期 （ 3 ～ 4 力末で）に加わった時に高度の難聴が 発生する確率が極めて高いことは注意しなければ ならない。

\section{1. 母体の感染}

風疹による難聴は風疹流行に伴って，ある時期 に，ある地方に難聴が多発するため，大きな社会 問題となることが多い。日本でも1964 年秋から 1965年初夏にかけて沖縄に風疹が流行し, 多数の 先天性風疹症候群が発生し, それらの子供達が中 学に進む年龄に達してきている。

風疹以外飞も。ウィルス咨患が胎生期難聴を和 こしてくることがあり, ポリオ, 麻疹, インフル エンザ，帯状疮疹などがわかっている，その他， トキソプラズマ症，梅毒などによって胎生期難聴 が発症してくる.

2. 薬物, 化学物質
ストレプトマイシン，カナマイシンを始めとし て,キニーネ,サリチル酸,アルコールなどにより 成人に感音性難聴が発症することはよく知られて いる.これらの物質が血行性に胎児の聴器を侵す であろうことは想像に難くなく, 胎生期難聴の原 因として重視されている. しかし実際の報告は極 めて少なく，その原因はこれらの薬物による障害 の特殊性がないため, その極め手となりにくいた めであるが，動物実験的にも証明されており，妊 婦への使用は注意されねね゙ならない. サリドマイ ドについての報告もみられる.

3. その他

母体の放射線被爆, 栄養障害, 特に糖尿病やビ タミンの過・不足, 内分泌障害, 酸素欠乏などが 胎生期難聴の原因になるといわれている.

\section{胎児の聴力検查は無理である}

高度の幼児難恥は，言語発達に密接な関係があ り，早期にこれを発見して言語治療などを始める ことが，言語発達の予後を良くするためには必要 である.このような理由から難聴の早期発見がの ぞまれ，胎児期にまで聴力検查を行ならというよ らなことまで考光られるようになってきた。しか しこれにはまだ多くの問題点が残っている.

最も大きな問題としては胎児に音をどのように して与えるかということであろう，最近の研究で は妊婦の腹壁に振動としての音を与光るのが普通 になっているがその場合の刺激の強さを音圧レべ ルや振動子の振巾で記載してあるにすぎない..音 压レベルは音の強さを物理的に表現する場合に最 も使用できる值ではあるが，とれはあく屯で空気 中の音波についてのものである、相手が腹壁とな ると全く状態は異なってしまうのである。振動子 の振巾でも事態は全く同じである. 腹壁の音響イ ンピーダンスがわからない現在，その記載は全く 無意味である．この点については腹壁を液体と考 えて撸算しょうとする試名はあるが，腹壁の厚さ， 弾性などを全く無視したもので問題にならない。 腹壁から耳に達するまでの伝音経路も不明である し, 刺激音がぞの程度の強さで胎児に達するのか 
全く未知である. 従って, 現状ではある測定值を 他の测定值と比較できないところが，聴力検査と しての価值がない最大の理由である. その他検査 の再現性，信頼度などの点でも聴力検査としては 問題が多く残っている.

このような検査で難聴があるか否かを判定する ことはできないし，将来とれが可能となったとし ても. 難聴胎児をどのように取り扱らかを解決し ない以前に検査のみを行ならといらことは慎重に 考慮すべきであろう。

\section{聴力検査はいつ行なうべきか}

胎児の聴力検查が行なえないことを明らかにし たが, 難聴の早期発見が 社会問題上要望されてい ることも間違いない，このような必要に応じて他 覚的な聴力検查法の発達はめざましく，聴性誘発 反応から蝸牛電気反応, 更に内耳神経の誘発反応 を利用した検査が最近では行なわれ，その応用年 齢は新生児にまで達している. 一方との信頼性は 年齢が加わるに従って良くなり，また難聴の治療 といら面からみると, 積極的な治療が可能な伝音 性難聴は, 大部分のものが耳鏡検査などによって 発見可能であるし, 補聴器とか言語治療が可能に なるのは 1 歳代からである：このようなことを考 虑すれば, 聴力検査は 1 歳前後に行ならのが最も 良いといらことになる。

最近, 難聴の早期発見ということで, 新生児に 対する簡単な聴力検査装置が，アメリカを中心と して販売されている、これは簡単な発信装置で,
これによって 新生児がその音をきこえているか否 か判定しょうというのである. 既に述べた如く, 新生児には聴反応としての体動がみられるのでは あるが，その反応の出現率は必ずしも良いとはい えず, しかも個体差も大きい. 乙かもその判定に は熟練が必要であり, 判定は極めて主観的にされ

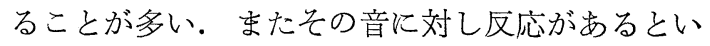
っても，難聴の疑いが全くないわけでもないし， 反応がないから難聴であるともいえない、反応が なかったので難聴の疑いがあると指摘されても, その乳児をどのように取り扱うのがよいかも現在 明らかでない。いずれにしても母親を心配させる だけのものである.

\section{文献}

1) 松崎 力, 鳥山 稔: 胎児及び新生児の聴力関 する文献的考察, Andiology. 8. 58, 1965.

2) Kawamura, S., Toriyama, M., Moggi, S. : Hearing Test for Infants by Means of Electroencephalography. Internal Association of Logopedics and Phoniatrics, 12. 263, 1962.

3) Peiper, A. : Cerebral Function in Infancy and Childhood, Consultants Bureau. 1963.

4) Relke, W., Frey, H. : Höruntersuchungen be : Neugeborenen. Z. Laryng. 45. 706, 1966.

5）坂部長正, 荒山 喬 : 音刺激による胎児の誘発反 応. 日耳鼻会報. 72. 752, 1969.

6）河村正三：留を伴った奇形群. 小児外科. 内科, 3. $785,1971$. 